\title{
THE IMAGE OF WOMAN AND FASHION IN TURKISH PAINTINGS OF THE REPUBLIC PERIOD
}

\author{
Oylum Öktem İşözen
}

Ph.D. Arts, oylumoisozen@gmail.com

\begin{abstract}
The proclamation of the Republic has brought changes in the social sphere in the political and the economic fields. Civil Law, with the enacted laws of The Dress and Hat Revolution, brought the place of the women to a more different place than it was in the Ottoman Empire. Women were given the right to elect and be elected. However, women's participation in working life, as a result of prolonged war in the late Ottoman period, has increased also as a necessity, but this has only been possible in Istanbul and large industrial cities. The readdressed education system with the Republic, has increased especially the ratio of women working in the field of education all over the country.

The changes, which have been experienced by women in social life, have affected their everyday clothes. It is known from the journal and archive of the palace, that especially women, in the 19th century palace and the top social classes, followed the Western fashion. However, these clothes were only becoming visible in domestic uses; the body was being completely covered while in use outside the home. With the Republic, women, who entered the public space, had the opportunity to follow the fashion that they wish. Unlike the Ottoman Empire, this change was observed in all social structures, not only in the top layer of society. It is possible to see traces of this in the press, in the early years of the Republic.

Written press has led to the spread of the new position of women in society and the preferred new dress code in the community. Women's magazines, even they were printed since the Ottoman period; when the literacy rate is concerned between the Ottoman and Republican era, it can be said that Republican magazines have been followed by a wider audience.

Republic was intended to awaken a national consciousness by supporting changes with the art of painting. In particular, Feyhaman Duran, Nazmi Ziya, Avni Arbas, Malik Aksel, Bedri Rahmi Eyuboglu, Neset Günal are important painters of the Republic period. The study aims to read the fashion of the period by using the image of women in the works of the Republic era painters. The female image and fashion used in the works of art will be compared with the overall fashion sense of the term.
\end{abstract}

Keywords: Turkish Painting, Women as Image, Fashion, Cloths, Periods of Turkish Republic.

\section{INTRODUCTION}

Although the Turkish painting art is represented by miniatures in the Ottoman Era, it can be asserted that a western-style painting art developed following the westernization. As the Ottoman Empire lost its prolonged military superiority over Europe, reform movements emerged within the country in the 17th century. Westernization efforts can be seen in the military, education and culture areas during the 18th and 19th centuries, within the scope of planned policies. However, such efforts failed to become widespread, either by 
social class or geographically.

As of the Republic Era, westernization and modernization were adopted as strict government policies, and realized in many areas covering the entire society and country. New rights were granted to women with the Civil Law, while literacy rate was increased with the reforms realized in the education area.

The primary goal of the Republic was to establish social order around the nation-state concept. Efforts were made to establish a scientific basis to achieve such goals, through institutions such as Turkish Language Society and Turkish Historical Society, and architectural styles were developed. However, art was utilized as an important tool in the Republic modernization and establishment of a nation.

A period of change and development in fine arts, similar to that of the West which began with the Renaissance period, was undergone in Anatolia, led by the principles and the light of the modern Republic established by Atatürk. The Turkish art thereby gained momentum, with painting and sculpture arts exhibiting rapid progress (Dal, 1983: 9).

Atatürk's modern vision was carried into practice in the painting and sculpture fields, as it was in all other areas. Artists greatly appreciated Atatürk, when he congratulated artists personally and purchased some paintings on the 6th Galatasaray Exhibition in 1924. This demeanour also set the pace for other statesmen, and was later adopted by the ministries and municipalities. (Elibal, 1973: 61).

The state adopted a supportive role for artists, by honouring them with gold, silver and bronze medal awards, and announcing that a certain number of artwork will be purchased each year from Turkish artists, for the purpose of establishing a museum (Tunçay et al, 1995: 539).

Painting, sculpture and art history education, as well as institutions providing such education programs were reviewed under the Law on Unification of Education, which was put into effect in 1924 (Dal, 1983: 13). The "Mekteb-i Sanâyi-i Nefîse-i Şâhâne" established in 1883, was thereby turned into the "State Academy of Fine Arts" with the assignment of the palace located in İstanbul-Fındıklı, and a group of 22 students was sent abroad in order to gain know-how in the science, technical and art fields (Yalçın et al, 2002: 208). Among these students, Hayrullah Örs, Mâlik Aksel, Şinasi Barutçu, İsmail Hakkı Uludağ and Mehmet Ali Atademir returned to Turkey in 1928-29, established the "Department of Art" in the Gazi Education Institute, and worked here as professors. Whereas, painters and sculptors such as Refik Fazıl (Epikman), Cevat Hâmit (Dereli), Mahmut Fehmi (Cûda), Muhittin Sebati and Ratip Aşir (Acudoğu) were among the founders of the "Association of Independent Painters and Sculptors", following their return to Turkey. The association organized its first exhibition in 1929, followed by others in various cities, especially Ankara and İstanbul (Dal, 1983: 12). The abovementioned events set the foundations of the painting art in Turkey.

"Atatürk" and the "War of Independence" were the predominant themes of the period in painting, where the compositions mostly stressed out the national unity, solidarity and independence concepts (Öztoprak, 2003: 735). In addition to paintings about women contributing to the efforts of independence of the Turkish Nation such as Halil Dikmen's oil painting titled "Village Women Carrying Ammunition in the War of Independence". Themes regarding education and social contribution of women were widely covered in the said period, such as Cemâl Tollu's "Villagers Reading the Alphabet" and Melek Celâl Sofu's "Woman in the Turkish Grand National Assembly" (Kurtuluş, 2005: 82-84).

In the 10th anniversary of the Republic, nationwide tours were organized in order to enable artists become more familiar with Anatolia, and the war of independence themed paintings resulting from the said experience were exhibited under the "Exhibition of Turkish Revolution". Atatürk personally visited the exhibition, and viewed each and every one of the artwork (Özgü, 1964: 42).

The Crown Prince Room of the Dolmabahçe Palace (former İstanbul Art and Sculpture Museum, current National Palaces Art Museum) was opened to public visit as Turkey's first "Art Gallery" on September 20 1937, with the directive of Atatürk, who considered fine arts as a requisite for modern life (Özgü, 1964: 43).

This paper will try to demonstrate the relation of the female figures in the Turkish early Republic era painting art with fashion of the period, while providing references from the printed publication of the same period. Thus, it is essential to provide an overview of the fashion concepts of the time.

\section{PERIODS OF FASHION}

20th century is the period where apparel is referred to as fashion in a general sense. Dressing style, which used to be created by palace tailors in both European and the Ottoman palaces, have begun to influence by designers as of late 19th century and early 20th century. 
The most prominent designer of the period is Jessie Franklin Turner of New York, who lived between 1881 and 1956. Turner influenced world fashion in the period between the First and the Second World Wars. The orange tea party dress shown in fig. 1 is an example of a combination of elements from world apparel and contemporary American style. Turner examined various museum collections for apparels from different cultures, and created designs based on her observations. It is known that Turner got her inspiration for the bird figure on this dress from an Uzbek dress she saw during her museum research (Fogg, 2014:218).

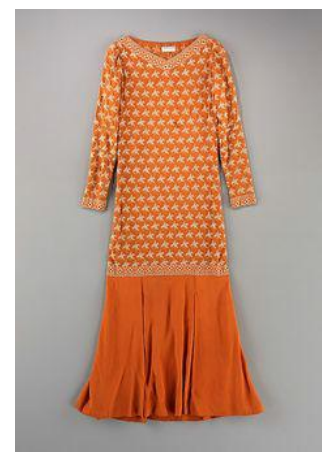

Fig. 1. Evening dress designed by Jessie Franklin Turner, 1925

Coco Chanel's greatest innovation to the ladies' fashion is her easy-to-wear and plain designs that are suitable to the needs of women who are adapted to business and social life. Three-piece jersey suit was the clothing that was most preferred by women. These suits, comprising of a patch-pocket cardigan, a skirt and a sweater, were made of fabrics knitted by using circular knitting machines developed by the French. This mass-produced apparel was the first fashion item completely targeted for public (See Fig. 2).

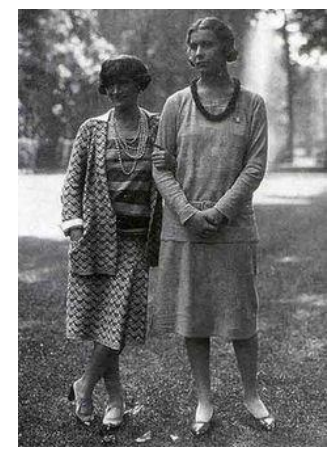

Fig. 2. Three-piece suit, 1929

The Coco Chanel design known as the Little Black Dress democratized elegance. This dress stood out as much as Ford Model T when first introduced, fashion magazines of the period therefore named this dress Chanel Ford and described it as a dress which can be worn by the entire world (See Fig. 3).

The dress has an asymmetrically-cut skirt. The skirt is ornamented with stones. Black colour, which was previously used only in mourning clothing, pulled away from such characteristic with Coco Chanel. This dress was preferred particularly by young ladies with free spirit. As an example of the masculine look of the 1920 s, this dress freed women from the limitations of the corset of the past. Women no longer had the hourglass look. Furthermore, breasts were intentionally flattened and ornamented with long bead necklaces, the most popular accessory of the period. The 1920s fashion necessitated the use of hosiery, as the skirt lengths shortened. The stockings were tight-fit on the legs. 


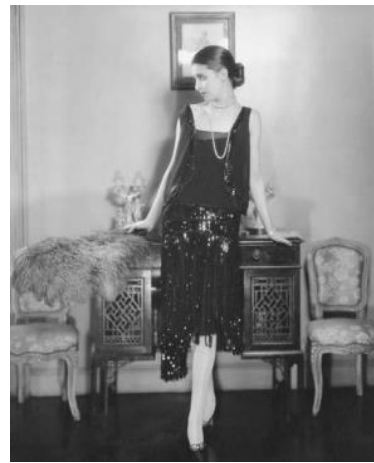

Fig. 3. Three-piece suit, 1929

Another outstanding characteristic of the 1920s was the bob haircut, popularized by the newly emerging movie stars. Abandonment of feminine long hair for masculine short hair got reaction. However, bob cut hair with thick forelock and neatly part in the middle gained wide acceptance particularly among young ladies with free spirit, and maintained its popularity until the present day (See Fig. 4).

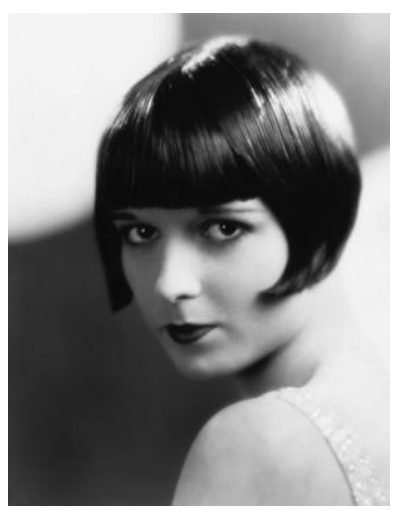

Fig. 4. Louise Brooks, US dancer and actress, 1929

The modern Art Deco trend was predominant in fashion between 1920 and 1930. This style is characterized by figures created using decorative elements, patterns and transitive colours inspired by the cultures of various eras and geographies. Women in Europe and the USA were reinforcing their existence in the business life and obtaining the right to elect and be elected, just like their fellows in the Republic of Turkey. These new rights liberated women to a greater extent, enabling them to perform 'manly' activities (such as smoking, driving, etc.). As a result, breasts were no more an important aspect of the woman body, and even more, women began to desire to be slim for the first time in fashion history. Ladies began to prefer nightgown-like, loose-fit, tubular dresses which concealed body lines.

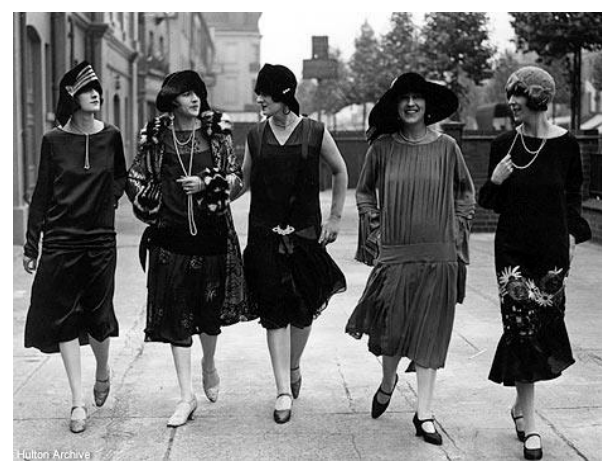

Fig. 5. Art Deco Fashion, 1920s

In the Art Deco fashion, the hipline of the dresses are lowered, and accentuated by either a strip or a belt. Hemlines rose over the knee between 1925 and 1928. Simplification of the woman silhouette allowed the use of extensive accessories, such as necklaces and hats. Shoes gained importance as hemlines got shorter.

Printed publications of the period include fashion articles accompanying dress drawings. For instance, the 
fashion article published on the Akşam Newspaper, dated April 24, 1934, describes that short-sleeve dresses are preferred, and wooden buttons, pleats and hemstitches are utilized (Fig. 6). The same article introduces five different models of dresses. The dress number one features red printed crepe Burmese rings over grey. The dress also includes grey crepe Burmese pleats, three at the hem, and two on the sleeves and one around the neck. The belt around the waist is red. The second dress is made of emerald green silk fabric with a diagonal pattern. The blouse and sleeves feature large wooden buttons. The belt is made of black suede. The third dress is made of faded pink marocain, with its blouse stitches providing a sense of bolero. Its sleeves and neck are hemstitched. The fourth dress is a light blue crepe Burmese dress. Its neck and sleeves feature triangular black lacquered buttons. The belt is made of black patent leather. Number five is a black crepe satin dress. Its hemline features a wide pleat and a flounce. The large neckline of the blouse also features a pleat. The gilet is made of light pink crepe satin.

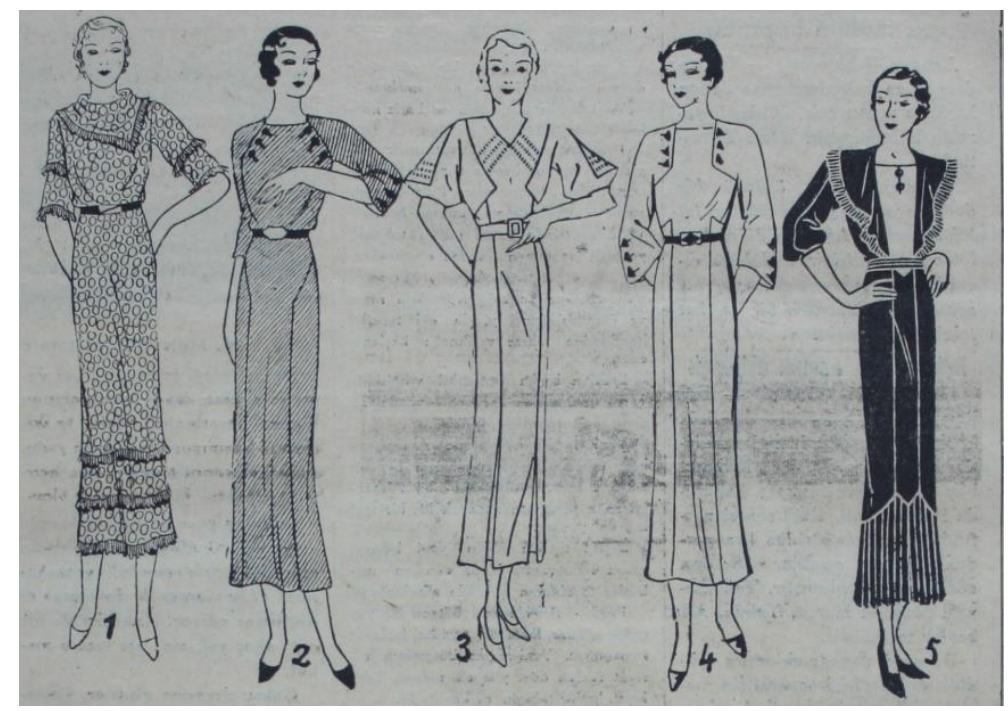

Fig. 6. Akşam, April 24, 1934

The newspaper advertisements also provide clues about the fashion of the era. An advertisement of tailormade high heel shoes made by Sümer Bank Beykoz Facilities was published on the daily newspaper Akşam, dated July 13, 1934, with the motto, "Ladies! Not only will your foes, but also your friends stare at your feet." (Fig. 7)

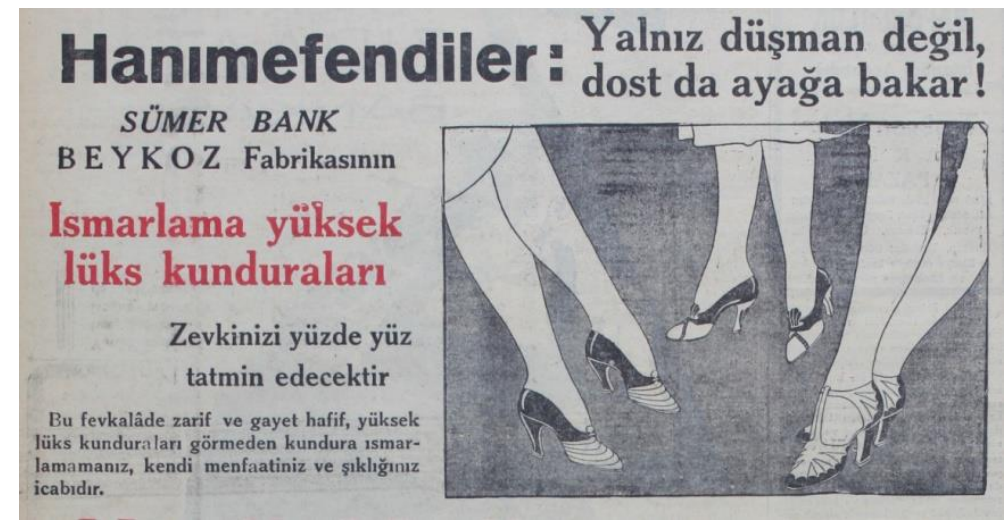

Fig. 7. Akşam, July 13, 1934

\section{FEMALE FIGURES IN THE TURKISH PAINTING ART AND FASHION}

Examples of female figures in the Turkish art prior to the Western influence can be observed in miniatures. Particularly, Levni, a miniature artist of the Tulip Era, in which the Ottoman had cultural communication and interaction with the West, prepared an album containing 21 male and 20 female figures, including gardeners, minions, masters, dervishes, dancers, Persians and Europeans. Most of the women in such figures are standing up, occasionally holding their skirts, putting on scarves, sniffing roses, but all are depicted in a manner where all their details can be seen (Renda, 1997: 1108). 
Although human figures are used in the Western style painting by artists such as Şeker Ahmet Paşa and Süleyman Seyyid, painters of military origin, the figure was never the main theme of the paintings of such artists. Osman Hamdi Bey is the artist who used figures as the main subject of the painting, in the Turkish Painting Art. In particular, his female figures demonstrate both contemporary ladies' wear and historical apparel. Another significant characteristic of Osman Hamdi Bey is the fact that, while Western orientalist artists depicted women as an object in the harem, Osman Hamdi Bey depicted reading, discussing, speaking women, and even aggrandized them to sit on a 'rahle' (medresa lecture tables; Fig. 8).

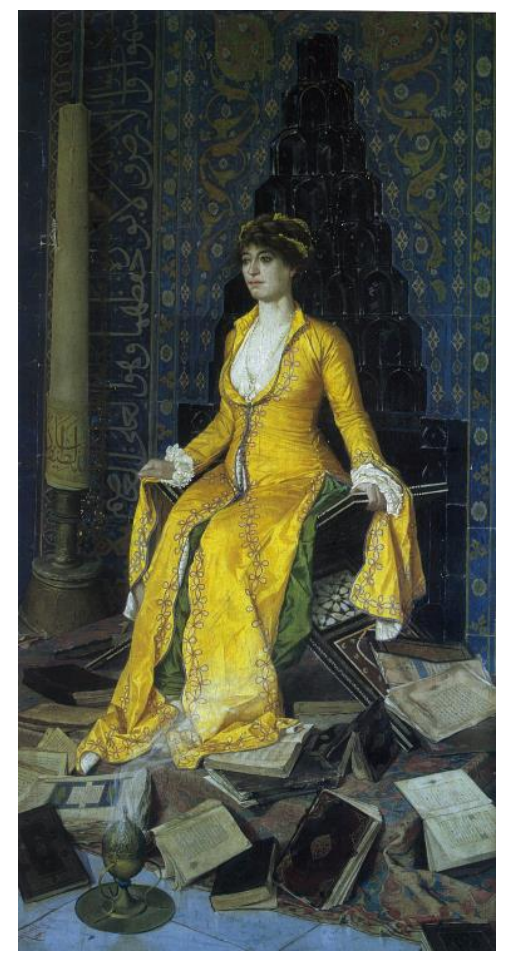

Fig. 8. Osman Hamdi Bey, La Genèse

The most significant characteristic of the Turkish Painting Art developing in the Republic era is that it is one of the primary evidences which demonstrate the modernization of Turkey. Artists of the period depicted the changes and progress introduced by the Republic. Many artists preferred to do so by placing women at the focus of their artwork.

The painting "Taksim Square" by Nazmi Ziya Güran (1881-1937) underlines the women's position in the liberated urban life, which has provided by the Republic, while exhibiting the fashion of the era. Taksim Square is a symbol of the Republic's modernization movement. Depiction of the Taksim Republic Monument with multi-story apartment blocks in the background and women dressed in modern style dignifies the modernization philosophy of the Republic. The details of the women's apparels are interesting (Fig. 9).

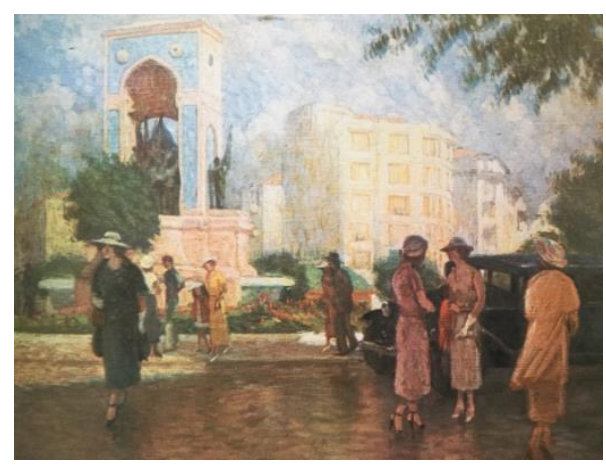

Fig. 9. Nazmi Ziya Güran, Taksim Square

Dresses seen in the fashion page of the Akşam Newspaper dated May 10, 1932 resemble those seen on Nazmi Ziya Güran's painting "Taksim Square". The artist depicts modernity using Taksim Square, modern apartment buildings and ladies' apparel, while the printed media provide hints to the contemporary ladies' 
apparels.

Portrait is the area where figurative painting is most widespread, and the work of İbrahim Çallı (b. 1882, Çal, Denizli - d.1960, İstanbul), a significant name in the 1914 generation, includes many portraits. Therefore, Çallı is the first name in the Republic era painting art, who comes to mind when portrait painters are concerned. Nude portraits, as well as face portraits are depicted indoors. The figure painting, "Portrait of a Lady" (Fig. 10) highlights the beauty and anatomy of the female body with an off-the-shoulder dress, while depicting an expression of loneliness on her face. In this painting, which gives an indoor impression aside from being a figure painting, the figure tries to hide her face under her hat, which gives her some extra mystery. The painting portraits a contemporary woman with a cigarette attached to a cigarette holder, whose expression strongly hints solitude. The hat depicted in the painting can also be seen on the daily newspaper Akşam, dated August 2, 1932 (Fig. 11).

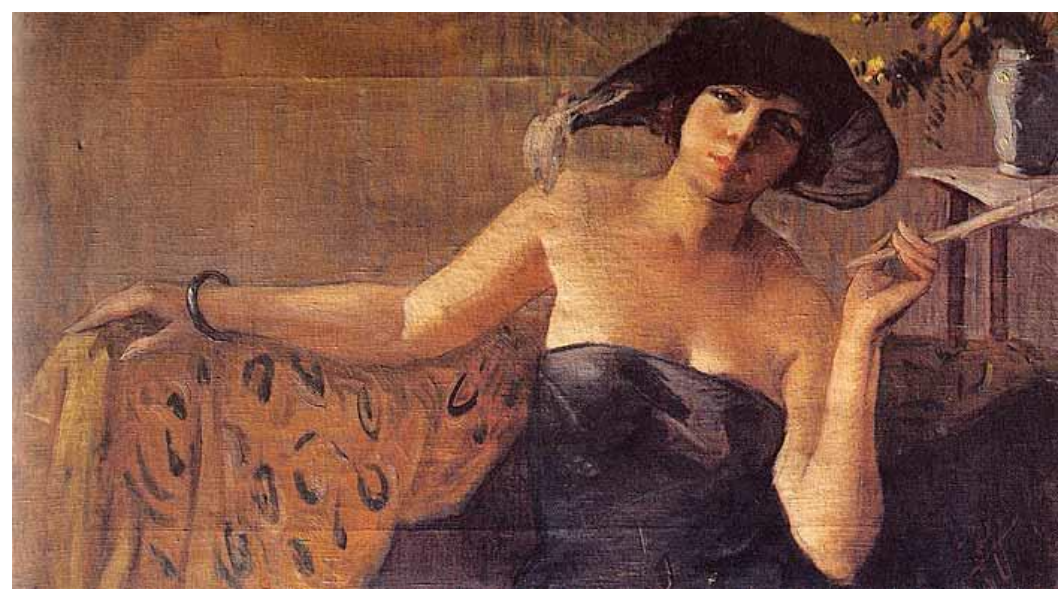

Fig. 10. İbrahim Çallı, "Portrait of a Lady", 1924,

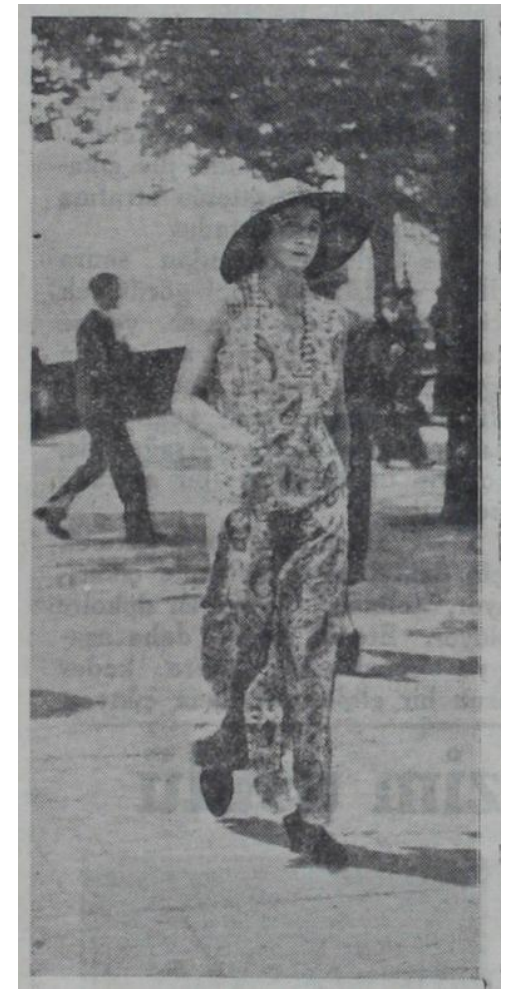

Fig. 11. Akşam, dated August 2, 1932.

The westernization movement of the Ottoman, emerging with the Tanzimat (reform) era, was limited to a specific social class, whereas the modernization philosophy of the Republic created effects more observable in the public realm. In particular, the granting of miscellaneous rights to women with the civil law enabled women to participate in social life more actively. Within such context, balls had symbolic importance in the 
Republic's modernization philosophy. Republic Balls are particularly important, where women attended in contemporary clothing and danced. The painting "The Ball", by Çallı, depicts women dressed in the fashion style of the 1930s, with shortened hems and wider neck lines (Fig. 12). The hair is cut short, ornamented by head accessories complementing the dresses. Very thin chiffons worn on shoulders are on the fly during dancing.

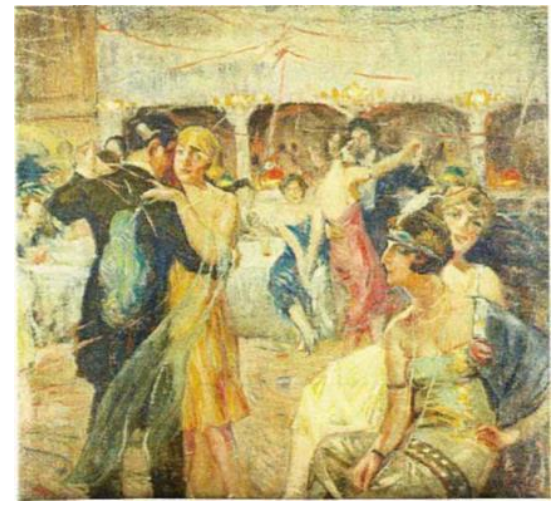

Fig. 12. İbrahim Çallı "The Ball"

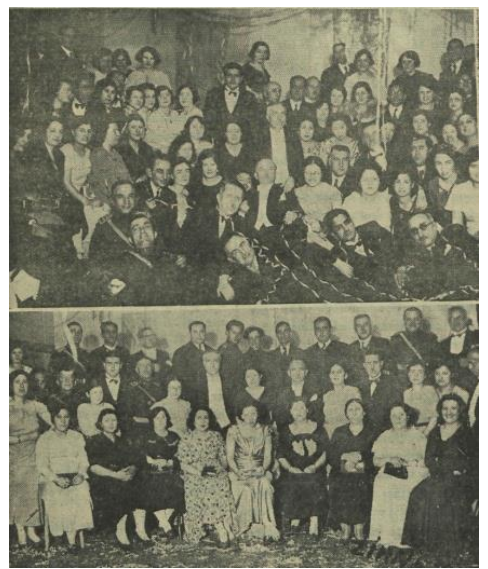

Fig. 13. Akşam, January 10, 1936

The painting "A Woman Standing", by Namık İsmail, depicts a female figure standing, wearing a long, closed-decollate dress (Fig. 14). The figure wears a long, loose cardigan over her dress. However, the prominent period-fashion aspect of this figure is her short hair. Short hair, first popularized by Hollywood actresses, was criticized in the beginning, not seen fit for women, but later gained acceptance.

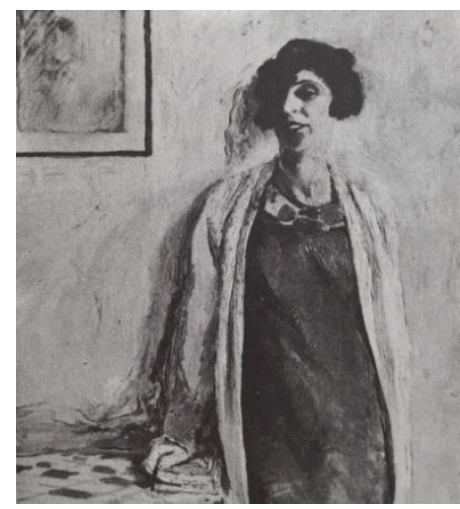

Fig. 14. Namık İsmail, "A Woman Standing"

The daily, Akşam, dated February 3, 1929 includes an article on the short hair trend. The article underlines that the short hair trend has begun following the World War, and as of 1926, it has become nearly as short as men's hair. The article also states that long hair was preferred in 1928, while short hair returned to the scene in 1929 (Fig. 15). 


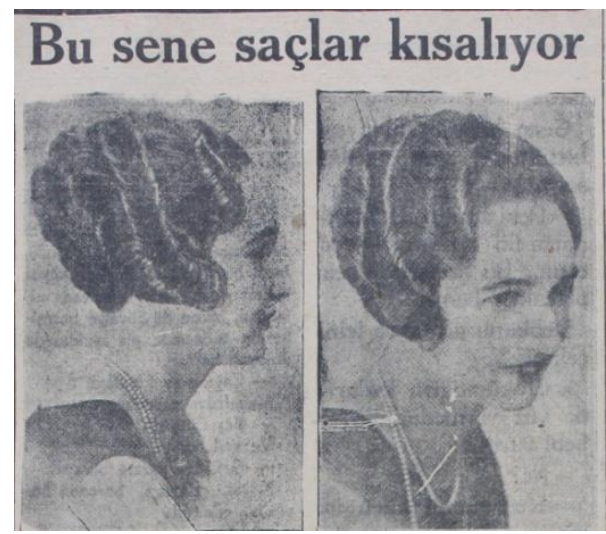

Fig. 15. Akşam, February 3, 1929

The artwork "A Woman with a Dog", by Şeref Akdik, demonstrates the fashion elements of 1930 (Fig. 16). The female figure, standing across a mirror, is depicted as wearing a long dress and slightly high heeled shoes, as well as a rounded hat, which is an accessory characteristic to that period. The embroidery on the collar and sleeves of the dress draws particular attention. The mid-aged female figure wears white gloves. In the daily Akşam, dated August 13, 1932, it can be seen that a hat similar to that in Şeref Akdik's painting is worn by Joan Crawford, a popular actress of the era (Fig.17). While the daily Akşam dated August 30, 1932 issues photographs of women dressed similarly with the female figure (Akşam, August 30, 1932: 7).

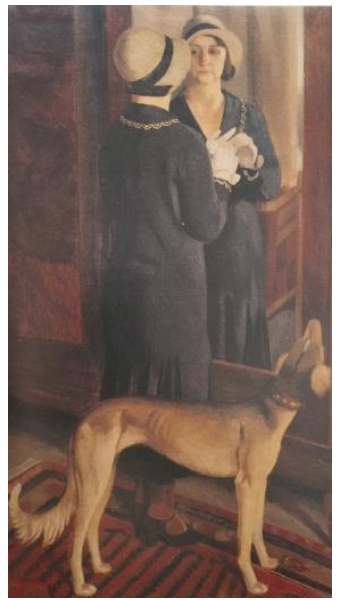

Fig. 16.

"A Woman with a Dog", by Şeref Akdik

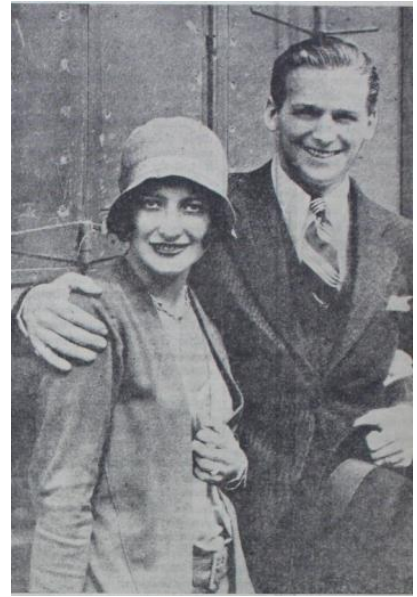

Fig. 17

Akşam, August 13, 1932

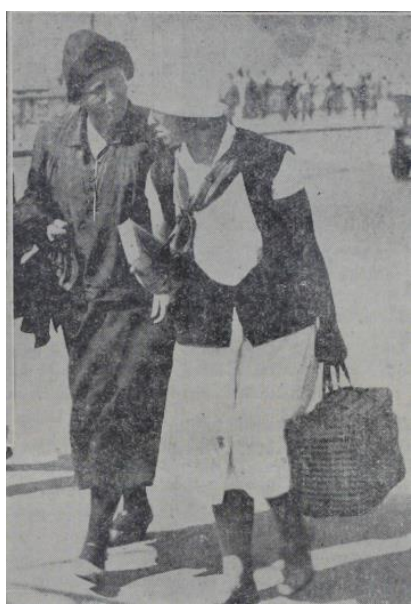

Fig. 18

Akşam, August 30, 1932

\section{CONCLUSION}

Figurative artwork is known to have existed since the era when the Ottoman painting art is represented by miniatures. It is seen that miniature artists, such as Levni, have focused on figures in the $17^{\text {th }}$ century, where relations with the Western world shifted to a cultural dimension. The $19^{\text {th }}$ century represents a peak period for the Ottoman Empire with respect westernization, with the efforts to maintain its political existence. Despite the failure of the reformist efforts in the areas of politics and economy, progress achieved in the social and cultural realms had longer-lasting effects. Development of the painting art influenced the Turkish art in the period of transition from landscape painting to figurative painting.

The Turkish painting art gained even more pace with the Republic. This is predominantly because of the Republic's policies towards utilizing art as a tool in the establishment of the society which has re-designed. Painting art was effectively utilized in the establishment of the nation state mind set. This concept can be studied under many areas including reflection of the Anatolian people into art, while the scope of this paper was limited specifically to female figures and fashion.

Apparels are an indication of social change. Within the Westernization period of the Ottoman Empire European fashion trends were followed especially in the palace life. However, this never spread to the public realm. Apparel was one of the most significant symbols following the establishment of the Republic. This 
symbolic meaning, most materially observed in the Hat Reform, was adopted by the painting art as a symbol of concepts such as development, modernism and modernization. Paintings of the era emphasize the modernization philosophy of the Republic particularly utilizing the image of women who freely wear contemporary clothes in public, thanks to the liberty introduced by the Republic.

The dialectic between the painting art and the painter is in the sole discretion of the painter. The image transferred by a painting to its audience is related to the way the artist interprets what he/she sees. This means distortion of reality in a positive or negative way. It can be asserted that, as photography gained popularity, a break has occurred in such dialectic between painting and the reality. This paper tried to research female figures in the Republic era painting art, based on fashion criteria, while providing reference images from newspapers of the same period. It can be suggested that two conclusions were reached as a result of this study. The first is that the clothing of the female figures depicted in the paintings are in accordance with the fashion trends of the period. The other conclusion is that the print media is widely utilized in the promulgation of the Republic's modernization philosophy. Fashion pages of the newspapers, as well as news articles emphasizing the outfits of domestic and foreign states people, their spouses and actors/actresses can evidence that the new regime emphasized clothing and the change undergone through clothing.

\section{REFERENCE LIST}

Akşam, April 24, 1934

Akşam, July 13, 1934

Akşam, February 3, 1929

Akşam, August 13, 1932

Akşam, August 30, 1932

Dal, E. (1983). Atatürk Döneminde Resim ve Resim Tartışmaları. Sanat Tarihi Yıllığı, (XII). İstanbul: İstanbul Üniversitesi Edebiyat Fakültesi Sanat Tarihi Araştırma Merkezi Yayınları.

Elibal, G. (1973). Atatürk ve Resim-Heykel. İstanbul: İş Bankası Yayınları.

Fogg, M. (2014). Modanın Tüm Öyküsü. Emre Gözgü (Çev.). İstanbul: Hayalperest Yayınevi.

Günsel Renda, “Minyatür Sanatı”, Eczacıbaşı Sanat Ansiklopedisi, 2.Cilt, YEM Yayıncılık, İstanbul

1997, p.1108

Kurtuluş, Y. (2005). Cumhuriyet'in Kuruluş Yıllarında Türk Resminde Yurttaş Kadın İmgesi. Nail Tan ve Hayrettin İvgin (Yay. Haz.). Uluslararası Atatürk ve Güzel Sanatlar Sempozyumu Bildirileri. (26-27 Ekim 2001/Ankara), Ankara: Cumhuriyet, Kültür ve Tanıtma Vakfı Yayınları.

Özgü, M. (1964). Atatürk'ün Edebiyat ve Sanat Anlayışı. Ankara: Türk Tarih Kurumu Basımevi.

Öztoprak, L (2003). Atatürk, Sanat, Sanatçı ve Resim. Atatürk Araştırma Merkezi Dergisi, (C.19), Ankara.

Renda, G (1997). Minyatür Sanatı. Eczacıbaşı Sanat Ansiklopedisi, 2.Cilt, YEM Yayıncılık, İstanbul

Tunçay, M. et al. (1995). Türkiye Tarihi 4, Çağdaş Türkiye (1908-1980). İstanbul: Cem Yayınları.

Yalçin, D. et al. (2002). Türkiye Cumhuriyeti Tarihi II, Ankara: Atatürk Araştırma Merkezi Yayınları. 